\title{
ANALISIS MODEL COOPERATIVE LEARNING TYPE STUDENT FACILITATOR AND EXPLAINING TERHADAP HASIL BELAJAR SISWA SEKOLAH DASAR
}

\author{
Roni Rodiyana \\ ronirodiyana@gmail.com \\ Universitas Majalengka
}

\begin{abstract}
ABSTRAK
Berdasarkan hasil observasi dan informasi yang didapat dari guru bahwa hasil belajar siswa kelas V kurang optimal. Model cooperative learning type student facilitator and explaining merupakan model pembelajaran yang memberikan kesempatan kepada siswa untuk mempresentasikan ide atau pendapat pada siswa lainnya sehingga siswa lebih aktif dalam proses pembelajaran. Tujuan penelitian ini untuk mengetahui seberapa besar pengaruh dari model cooperative learning type student facilitator and explaining terhadap hasil belajar siswa di kelas V SDN Cikasarung. Sebelum dan sesudah diterapkannya model pembelajaran student facilitator and explaining dalam proses pembelajaran apakah ada atau tidak peningkatan hasil belajar siswanya, dapat diketahui peningkatan hasil belajar siswa dengan rata-rata pretest siswa yaitu 61,5 dan postest 76,75 . Penelitian ini bersifat eksperimen dengan menggunakan metode kuantitatif dengan desain one grup pretest-postest. Alat pengumpulan data yang digunakan dengan soal pilihan ganda dan essay untuk mengetahui peningkatan hasil belajar siswa. Sampel yang digunakan dalam penelitian ini berjumlah 20 orang siswa dengan teknik pengambilan sampel yaitu teknik Nonprobality Sampling dengan jenis Sampling Jenuh. Analisis data dengan uji $\mathrm{t}$ korelasi product moment. Dari hasil penelitian dengan pengolahan data menggunakan uji $\mathrm{t}$ korelasi product moment menunjukan bahwa nilai signifkansi diperoleh sig 0,000 kurang dari 0,05 sehingga dapat disimpulkan terdapat pengaruh yang signifikan terhadap hasil belajar siswa setelah penerapan model cooperative learning type student facilitator and explaining, terdapat pengaruh sangat positif, dengan kategori sangat setuju sehingga $\mathrm{H}_{0}$ ditolak.
\end{abstract}

Kata kunci: Hasil belajar siswa, model cooperative learning type student facilitator and explaining 


\section{Pendahuluan}

Salah salah satu masalah yang dihadapi dunia pendidikan saat ini adalah masalah lemahnya pelaksanaan proses pembelajaran yang diterapakan para guru di sekolah. Proses pembelajaran yang terjadi selama ini kurang mampu mengembangkan kemampuan berpikir peserta didik, sehingga hasil belajarnya kurang optimal. Pelaksanaan proses pembelajaran yang berlangsung di kelas hanya diarahkan pada kemampuan siswa untuk menghafal informasi, otak siswa dipaksa hanya untuk mengingat dan menimbun berbagai informasi tanpa dituntut untuk memahami informasi yang diperoleh untuk menghubungkannya dengan situasi dalam kehidupan sehari-hari.

Hasil belajar merupakan perubahan perilaku yang diperoleh pembelajaran setelah mengalami aktivitas belajar (Anni, 2006: 5). Hasil belajar siswa tidaklah sama, ada yang baik dan ada yang kurang baik. Kebanyakan siswa mengalami masalah dalam belajar, sehingga masalah tersebut berdampak terhadap hasil belajar siswa yang rendah.

Faktor Ekstern yang mempengaruhi hasil belajar salah satunya yaitu faktor model pembelajaran. Menurut Arends, sebagaimana dikutip oleh Suprijono (2011: 46), model pembelajaran mengacu pada pendekatan yang akan digunakan, termasuk di dalamnya tujuan-tujuan pembelajaran, tahap-tahap dalam kegiatan pembelajaran, lingkungan pembelajaran, dan pengelolaan kelas. Selain siswa, unsur terpenting yang ada dalam kegiatan pembelajaran adalah guru. Seorang guru dalam menyampaikan materi perlu memilih model yang sesuai dengan keadaan kelas atau siswa sehingga siswa merasa tertarik untuk mengikuti pelajaran yang diajarkan. Model mengajar guru yang kurang baik akan memengaruhi hasil belajar siswa menjadi kurang baik pula. Misalkan guru kesehariannya dalam mengajar biasa menggunakan model ceramah, siswa akan menjadi bosan, mengantuk, hanya mencatat, akhirnya siswa menjadi pasif. Jelaslah bahwa model pembelajaran itu memengaruhi hasil belajar. Oleh karena itu, seorang guru harus yang progresif berani mencoba modelmodel pembelajaran yang baru untuk meningkatkan keaktifan siswa. Dalam kegiatan belajar mengajar, seorang guru sebaiknya memposisikan seorang siswa sebagai insan yang perlu dihargai potensinya, sehingga hendaknya seorang siswa diberi kesempatan untuk aktif sehingga dapat mengembangkan potensinya. Maka dari itu, proses belajar mengajar perlu suasana yang akrab, terbuka dan saling menghargai.

Observasi yang dilakukan masih terdapatnya permasalahan terkait dengan pembelajaran yang dilaksanakan, terutama pada penggunaan model pembelajaran yang digunakan guru pada saat pembelajaran. Guru masih menggunakan model pembelajaran konvesional, yang membuat siswa kurang memahami terhadap materi yang disampaikan guru pada saat proses pembelajaran. Berdasarkan hasil observasi yang dilakukan ditemukan bahwa hasil belajar siswa kurang optimal. Pertama, mulai dari aspek kognitif, yakni aspek pengetahuan, pemahaman, karena melihat dari hasil belajar yang masih rendah di bawah KKM. Kedua, aspek afektif dan aspek psikomotor yakni yang belum mencapai tujuan pembelajaran yang direncankan, dari jumlah keseluruhan siswa kelas $\mathrm{V}$ adalah 20 siswa diantaranya siswa laki-laki 11 orang siswa dan perempuan 9 orang siswa, KKM-nya adalah 75 , dan yang mencapai nilai KKM hanya 8 siswa dari 20 siswa, dan sisanya belum mencapai nilai KKM yang telah di tentukan oleh sekolah. Sehingga dapat disimpulkan bahwa tujuan pembelajaran yang telah ditentukan belum tercapai.

Untuk mengatasi permasalahan tersebut diperlukannya penggunaan model pembelajaran yang dapat membuat pembelajaran lebih bermakna bagi siswa dan meningkatkan hasil belajar kognitif, afektif dan psikomotor siswa yang optimal 
dan membuat siswa aktif dalam proses pembelajaran. Dengan menggunakan model Cooperative Learning Type Student Facilitator And Explaining diharapkan dapat mengajak siswa mandiri dalam mengembangkan potensi mengungkapkan gagasan berpendapat.

Dimyati dan Mudjiono (2009: 85) model pembelajaran Student Facilitator and Explaining merupakan model pembelajaran dimana siswa/peserta didik belajar mempresentasikan ide/pendapat pada rekan peserta didik lainnya. Model pembelajaran Student Facilitator and Explaining merupakan salah satu model pembelajaran kooperatif yang melibatkan keaktifan siswa dalam proses pembelajaran. Model pembelajaran kooperatif dengan menggunakan kelompok-kelompok kecil dengan jumlah anggota tiap kelompok 4-5 siswa secara heterogen (Trianto, 2007: 52). Karena pada dasarnya apabila pembelajaran dapat diajarkan melalui percobaanpercobaan yang dilakukan sendiri oleh siswa saat proses pembelajaran akan membuat siswa lebih paham tentang informasi yang disampiakan oleh guru karena siswa mengalami langsung atau mempraktekannya sendiri.

1. Manfaat bagi guru

a. Memberikan wawasan kepada guru tentang penerapan model

Cooperative Learning Type Student Facilitator And Explaining dalam proses pembelajaran.

b. Memberikan masukan kepada guru tentang berbagai kelebihan dan kekurangan dari model Cooperative Learning Type Student Facilitator And Explaining.

2. Manfaat bagi siswa

Diharapkan dapat meningkatkan hasil belajarnya melalui model Cooperative Learning Type Student Facilitator And Explaining.

\section{Hasil Belajar Siswa}

Belajar merupakan proses manusia untuk mencapai berbagai macam kompetensi, keterampilan dan sikap. Belajar menurut Slameto (2010: 2) adalah "Suatu proses usaha yang dilakukan seorang untuk memperoleh suatu perubahan tingkah laku yang baru secara keseluruhan, sebagai hasil pengalamannya sendiri dalam interaksi dengan lingkunganya". Kemudian menurut Baharudin dan Wahyuni (2007: 13) menyatakan belajar adalah usaha untuk mencapai kepandaian, atau ilmu merupakan usaha manusia untuk memenuhi kebutuhannya mendapatkan ilmu, atau kepandaian yang belum dipunya sebelumnya. Sehingga dengan belajar itu manusia jadi tahu, memahami, mengerti, dapat melaksanakan dan memiliki sesuatu.

Berdasarkan uraian di atas, maka dapat disimpulkan bahwa belajar ialah suatu proses yang dilakukan oleh individu untuk memperoleh perubahan perilaku yang baru secara keseluruhan, sebagai hasil dari pengalaman individu itu sendiri dalam interaksi dengan lingkungannya. Oleh karena itu, kemampuan manusia untuk belajar merupakan karakteristik penting yang membedakan manusia dengan mahluk hidup lainnya. Aktivitas yang dilakukan dalam belajar tidak hanya dipahami sebagai aktivitas yang dilakukan oleh pelajar saja karena belajar merupakan aktivitas yang dilakukan seseorang untuk mendapatkan perubahan dalam dirinya melalui pelatihanpelatihan atau pengalaman-pengalaman.

Purwanto (2011: 44) Hasil belajar dapat dijelaskan dengan memahami dua kata yang membentuknya, yaitu "hasil" dan "belajar". Pengertian hasil (product) menunjuk pada suatu perolehan akibat dilakukannya suatu aktivitas atau proses yang mengakibatkan berubahnya input secara fungsional. Sedangkan belajar dilakukan untuk mengusahakan adanya perubahan perilaku pada individu yang belajar. Perubahan perilaku itu merupakan perolehan yang menjadi hasil belajar, selain hasil belajar kognitif yang diperoleh siswa.

Menurut Jihad (2012: 16) menyatakan bahwa hasil belajar yang dicapai oleh siswa sangat erat kaitanya dengan rumusan tujuan 
instruksional yang direncanakan guru sebelumnya dikelompokan ke dalam tiga kategori, yakni aspek kognitif, afektif dan psikomotor.

Ranah kognitif berkenaan dengan hasil belajar intelektual. Menurut Anderson dan Krathwohl (2002: 45) ranah kognitif terdiri dari enam aspek, yakni pengetahuan (knowledge), pemahaman (Conprehension), aplikasi (Aplication), Analisis (Analysis), sintesis (Synthesis), dan Evaluasi (Evaluation).

Selanjutnya ranah afektif berkenaan dengan sikap yang terdiri dari lima aspek, yakni penerimaan (Receiving), jawaban atau reaksi (Responding), dan Internalisasi (Internalitation).

Serta yang terakhir ranah psikomotor berkenaan dengan hasil belajar keterampilan dan kemampuan bertindak. Menurut djemari (2004: 4-5) keterampilan psikomotor berhubungan dengan gerak, yaitu, menggunakn otot, seperti lari, melompat, melukis, berbicara, membongkar, dan memasang peralatan dan sebagainya. Ada enam aspek ranah psikomotor, yakni gerakan refleks, keterampilan gerakan, dasar, kemampuan perseptual, keharmonisan, atau ketepatan, gerakan keterampilan kompleks, dan gerakan ekspresif dan interpreatif.

Menurut Slameto (2010: 112), faktorfaktor yang memengaruhi belajar banyak jenisnya, tetapi dapat digolongkan menjadi dua golongan yaitu faktor intern dan faktor ekstern. Faktor intern adalah faktor yang ada dalam diri individu yang sedang belajar, sedangkan faktor ekstern adalah faktor yang ada di luar individu.

\section{Karakteristik Siswa Kelas V}

Masa usia sekolah dasar kelas V sebagai masa kanak-kanak akhir yang berlangsung dari usia sepuluh tahun hingga kira-kira usia sebelas tahun atau dua belas tahun. Karakteristik utama siswa sekolah dasar kelas $\mathrm{V}$ adalah mereka menampilkan perbedaan-perbedaan individual dalam banyak segi dan bidang, diantaranya, perbedaan dalam intelegensi, kemampuan dalam kognitif dan bahasa, perkembangan kepribadian dan perkembangan fisik anak.

Menurut Kusuma (2007: 42)

karakteristik anak umur 10-13 tahun atau kelas 5-6 adalah sebagai berikut:

1) Karakteristik Fisik, diantaranya sebagai berikut: a) otot tangan dan lengan lebih berkembang; b) anak-anak menjadi sadar akan keadaan jasmaninya; c) anak laki-laki senang pertandingan yang kasar dan keras; d) anak-anak pada masa ini ada perbaikan kecepatan bereaksi; e) anak-anak umur ini gemar akan jenis olahraga pertandingan; f) koordinasi anak-anak umur ini baik, karena itu sudah dapat diajarkan jenis-jenis kegiatan yang agak sukar, artinya kegiatan yang memerlukan gerakan gabungan; g) keadaan jasmani terlihat kuat, kokoh dan sehat.

2) Karakteristik Sosial dan Emosional, di antaranya sebagai berikut: a) Bersamaan dengan proses kematangan fisik, emosinya pada waktu itu tidak stabil; b) Karena hasrat bergabung dan adanya perbedaan cara menimbulkan salah paham antara anak satu dan lainnya; c) Anak usia ini mudah timbul takjub; d) Anak-anak usia ini emosi biasa berontak; e) Mempunyai tanggapan positif terhadap penghargaan dan puji-pujian; f) Anakanak masa ini mempunyai pandangan kritis terhadap tindakan orang dewasa; g) Rasa kebanggaan berkembang; h) Setiap hal yang dikerjakan, menginginkan adanya penghargaan atau pengenalan; i) Ingin pengenalan atau penghargaan dari kelompok; j) Anak-anak masa ini mudah memperoleh teman. Lebih senang; k) melakukan kegiatan dalam kelompok dari pada kegiatan yang bersifat perorangan (individual).

3) Karakteristik Mental diantaranya sebagai berikut: a) anak-anak masa ini lebih gemar bermain-main dengan 
mempergunakan bola; b) anak-anak lebih berminat dalam permainanpermainan beregu atau berkelompok; c) anak-anak sangat terpengaruh apabila ada kelompok yang menonjol atau mencapai prestasi tinggi; d) sementara anak masa ini mudah putus asa, karena itu usahakan; e) bangun kembali atau bangkit kembali apabila tidak berhasil dalam mencapai sesuatu; f) dalam melakukan sesuatu usaha, selalu berusaha mendapat persetujuan dari guru terlebih dahulu; g) anak-anak masa ini pada umumnya memperhatikan soal waktu, karena itu berusaha bekerja tepat pada waktunya.

\section{Model Cooperative Learning}

Menurut Trianto (2014: 23) Model pembelajaran adalah suatu perencanaan atau suatu pola yang digunakan sebagai pedoman dalam merencanakan pembelajaran di kelas atau pembelajaran dalam tutorial dan untuk menentukan perangkat-perangkat pembelajaran termasuk didalamnya buku buku, film, komputer, kurikulum dan lain-lain.

Menurut Majid (2013:

Pembelajaran kooperatif adalah strategi pembelajaran yang melibatkan partisipasi siswa dalam suatu kelompok kecil untuk saling berinteraksi. Dalam sistem belajar kooperatif, siswa belajar kerja sama anggota lainnya. Kemudian Abdulhak (2001: 174) menjelaskan bahwa pembelajaran kooperatif dilaksanakan melalui sharing proses antara peserta didik, sehingga dapat mewujudkan pemahaman bersama antara peserta didik itu sendiri.

Menurut Isjoni (2009: 15) dalam pembelajaran kooperatif, terdapat beberapa teknik yang dapat digunakan dalam proses belajar mengajar di kelas yaitu: mencari pasangan (make a match); bertukar pasangan; berpikir berpasangan berempat (think pair share); berkirim salam dan soal; kepala bernomor (numbered heads); jigsaw; STAD (student team achievement division); picture and picture; student facilitator and explaining

\section{Model Cooperative Learning Tipe Student Facilitator and Explaining}

Menurut Suyatno (2009: 15) Model cooperative learning tipe student facilitator and explaining merupakan suatu model yang memberikan kesempatan kepada siswa untuk mempresentasikan ide atau pendapat pada siswa lainnya.

Menurut Suprijono (2011: 128) Langkah-langkah pembelajaran dengan model cooperative learning tipe student facilitator and explaining yaitu sebagai berikut:

1) Guru menyampaikan kompetensi yang ingin dicapai.

2) Guru menyajikan materi, memberikan kesempatan siswa untuk menjelaskan kepada siswa lainnya baik melalui bagan atau peta konsep maupun yang lainnya.

3) Guru menyimpulkan ide atau pendapat dari siswa.

4) Guru menjelaskan semua materi yang disajikan pada saat itu, dan penutup.

Menurut Asma (2006: 120) Model cooperative learning tipe student facilitator and explaining menekankan pada pembelajaran yang mengaktifkan siswa dan penyajian materi yang dilakukan dengan menghubungkan kegiatan sehari-hari dan lingkungan siswa sehingga siswa lebih termotivasi untuk belajar.

Menurut Mahmud (2010: 45) Dalam Model pembelajaran ini akan dapat berjalan sesuai dengan yang diharapkan apabila siswa secara aktif ikut serta dalam merancang materi pembelajaran yang akan dipresentasikan maka siswa akan lebih bisa mengerti dan mampu memahaminya untuk mengungkapkan ide, selain itu juga dapat mengajak siswa mandiri dalam mengembangkan potensi mengungkapkan gagasan berpendapat.

Menurut Hidayanti (2008: 43) Berikut ini akan dipaparkan beberapa kelebihan 
model cooperative learning tipe student facilitator and explaining yaitu:

1) Siswa diajak untuk dapat menerangkan kepada siswa lain.

2) Dapat mengeluarkan ide-ide yang ada dipikirannya sehingga lebih dapat memahami materi tersebut.

3) Materi yang disampaikan lebih jelas dan konkrit.

4) Dapat meningkatkan daya serap siswa karena pembelajaran dilakukan dengan demonstrasi.

5) Melatih siswa untuk menjadi guru, karena siswa diberikan kesempatan untuk mengulangi penjelasan guru yang telah dia dengar.

6) Memacu motivasi siswa untuk menjadi yang terbaik dalam menjelaskan materi ajar.

7) Mengetahui kemampuan siswa dalam menyampaikan ide atau gagasan.

\section{Metode Penelitian}

Desain yang akan digunakan pada penelitian ini disesuaikan dengan variabel yang akan diteliti, yaitu dengan desain PreExperimen dengan jenis One-Group Pretest-Posttest Design.

Dalam penelitian ini hanya akan satu kelas yang digunakan untuk diteliti dan akan diberi treatment (perlakuan) dan selanjutnya akan diobservasi hasilnya. Kelas tersebut akan diberi pretest terlebih dahulu untuk mengetahui sejauh mana penguasaan materi sebelum dilakukan treatment yang telah disampaikan oleh guru dari hasil belajarnya, dan mengetahui sejauh mana hasil belajar siswa sebelum diberikan perlakuan.

Setelah hasil pretest diketahui kemudian kelas eksperimen tersebut diberi treatment perlakuan dengan menggunakan model cooperative learning tipe student facilitator and explaining. Setelah memberikan treatment (perlakuan) kemudian memberikan posttest untuk mengetahui hasil pembelajaran melalui model cooperative learning tipe student facilitator and explaining dan pengaruhnya terhadap hasil belajar siswa.

Teknik sampel yang akan digunakan dalam penelitian ini adalah Nonprobability Sampling dengan jenis Sampling Jenuh. Menurut Sugiyono (2012: 122) Nonprobability Sampling adalah teknik pengambilan sampel yang tidak memberi peluang/kesempatan sama bagi setiap unsur atau anggota populasi untuk dipilih menjadi sampel." Sedangkan jenis Sampling jenuh menurut Sugiyono (2008: 124) "merupakan teknik penemuan sampling bila semua anggota populasi berjumlah relatif kecil, kurang dari 30 orang."

Dalam penelitian ini yang dijadikan sampel penelitian adalah siswa kelas V SD Negeri Cikasarung yang berjumlah 20 orang di Kecamatan Majalengka Kabupaten Majalengka.

Penelitian ini meliputi tiga tahap yaitu tahap persiapan penelitian, tahap pelaksanaan penelitian dan tahap akhir penelitian.

1) Tahap persiapan penelitian

a) Melakukan studi literatur terhadap teori yang relevan mengenai model pembelajaran yang digunakan.

b) Konsultasi dengan pihak sekolah dan guru bidang studi mengenai waktu penelitian, populasi dan sampel yang akan dijadikan sebagai subjek dalam penelitian.

c) Penyusunan perangkat pembelajaran yaitu berupa RPP, skenario pembelajaran dan LKS.

d) Pembuatan instrumen penelitian berupa tes pilihan ganda dan essay untuk mengukur hasil belajar siswa, lembar observasi untuk mengukur keterlaksanaan model yang digunakan.

e) Melakukan uji coba instrumen tes.

f) Menganalisis hasil uji coba instrumen penelitian untuk mengetahui layak atau tidaknya soal tersebut digunakan sebagai instrumen penelitian.

2) Tahap pelaksanaan penelitian 
a) Memberikan tes awal untuk mengukur hasil belajar siswa sebelum diberi perlakuan (treatment).

b) Memberikan perlakuan yaitu dengan cara menerapkan model cooperative learning tipe student facilitator and explaining.

c) Memberikan tes akhir untuk mengukur peningkatan hasil belajar siswa setelah diberi perlakuan (treatment).

3) Tahap Akhir penelitian

a) Mengolah data hasil pretest dan postest serta menganalisis instrumen yang lain seperti lembar observasi.

b) Menganalisis data hasil penelitian dan membahas temuan penelitian.

c) Memberikan kesimpulan berdasarkan hasil pengolahan data.

d) Memberikan rekomendasi berdasarkan hasil penelitian.

Untuk mendapatkan data yang mendukung dalam penelitian ini digunakan beberapa instrumen penelitian. Instrumen yang digunakan dalam penelitian ini adalah sebagai berikut:

1. Tes

Butir tes terdiri dari butir pretest dan posttest yang diukur dengan menggunakan tes pilihan ganda dan essay dengan jumlah soal 30 butir, pilihan ganda 20 soal dan essay 10 soal.

2. Lembar Observasi

Lembar observasi digunakan sebagai lembar pengamatan yang digunakan untuk mengukur hasil belajar siswa selama proses pembelajaran berlangsung. Lembar observasi ada dua yaitu lembar observasi siswa dan guru.

\section{Uji Coba Instrumen}

1. Validitas

Menurut Arikunto (2008: 76) "sebuah item dikatakan valid apabila mempunyai dukungan yang besar terhadap skor total. Skor pada item menyebabkan skor total menjadi tinggi atau rendah." validitas dapat kita cari dengan menghubungkan skor keseluruhan siswa dalam satu item (X) dengan skor keseluruhan yang diperoleh semua siswa (Y) melalui korelasi product moment Pearson dengan angka kasar berikut ini:

$r_{x y}=\frac{n \sum x y-\left(\sum x\right)\left(\sum y\right)}{\sqrt{\left.\left\{n \sum X^{2}-\left(\sum X^{2}\right)\right\}\left\{N \sum Y^{2}-\sum Y^{2}\right)\right\}}}$

Keterangan:

$r x y=$ Koefesien korelasi antar variabel $\mathrm{X}$ dan variabel Y

$\mathrm{N}=$ Jumlah peserta tes

$\mathrm{X}=$ Skor tiap item

$\mathrm{Y}=$ Skor total

$\sum \mathrm{XY}=$ Jumlah perkalian $\mathrm{XY}$

Menurut Arikunto (2008: 75) "koefisien korelasi selalu terdapat antara 1.00 sampai 1.00." koefisien negatif menunjukan hubungan kebalikan sedangkan koefisien positif menunjukan adanya kesejajajaran untuk mengadakan interpretasi besarnya, koefisien korelasi adalah sebagai berikut:

\begin{tabular}{|c|c|}
\hline $\begin{array}{c}\text { Tingkat } \\
\text { Keberhasilan }\end{array}$ & Kategori \\
\hline $0,800-1,00$ & Validitas sangat tinggi. \\
\hline $0,600-0.800$ & Validitas tinggi \\
\hline $0.400-0.600$ & Validitas Cukup \\
\hline $0,200-0.400$ & Validitas rendah \\
\hline $0,00-0.200$ & Validitas sangat rendah \\
\hline
\end{tabular}

2. Reliabilitas

Menurut Arikunto (2008: 86) "reliabilitas adalah tingkat keajegan (konsistensi) suatu tes. yakni sejauh mana suatu tes dapat dipercaya untuk menghasilkan skor yang ajeg/konsisten (tidak berubah)." Rumus yang digunakan untuk menghitung reliabilitas tes adalah rumus Alfa $(\alpha)$ Cronbach sebagai berikut:

$$
\mathrm{r}=\left(\frac{\mathrm{k}}{\mathrm{k}-1}\right) \frac{\mathrm{SD}_{t}{ }^{2}-\Sigma(\mathrm{SD} i)^{2}}{(\mathrm{SD})_{t}{ }^{2}}
$$

Keterangan:

$$
\begin{aligned}
\mathrm{R}= & \text { Koefesien reliabilitas skala } \\
\mathrm{K}= & \text { Banyaknya item } \\
\mathrm{SD}_{t}{ }^{2}= & \text { Varians skor seluruh item } \\
& \text { menurut skor siswa perorangan }
\end{aligned}
$$


$\sum \mathrm{S}_{i}{ }^{2}=\begin{aligned} & \text { Jumlah varians skor seluruh } \\ & \text { pernyataan menurut skor item }\end{aligned}$ tertentu

Tolak ukur untuk mengiterprestasikan derajat reliabilitas tes yaitu:

\begin{tabular}{|c|c|}
\hline $\begin{array}{c}\text { Tingkat } \\
\text { Keberhasilan }\end{array}$ & Kategori \\
\hline $0,81-1,00$ & Sangat Tinggi \\
\hline $0,61-0,80$ & Tinggi \\
\hline $0,41-0,60$ & Cukup \\
\hline $0,21-0,40$ & Rendah \\
\hline 0,20 & Sangat Rendah \\
\hline
\end{tabular}

\section{Taraf Kesukaran Soal}

Pengujian ini bertujuan untuk mengetahui tingkat kesukaran dari tiap item soal apakah mudah, sedang, atau sukar. Rumus yang digunakan adalah sebagai berikut:

$$
\mathrm{p}=\frac{B}{J S}
$$

Keterangan:

$\mathrm{P} \quad=$ indeks penelitian untuk setiap butir

$\mathrm{B}=$ skor seluruh siswa peserta tes untuk setiap butir soal

$\mathrm{JS}=$ skor maksimal yang mungkin diperoleh peserta tes

\begin{tabular}{|c|c|}
\hline $\mathrm{P}$ & Klasifikasi \\
\hline $\mathrm{P}=0,00$ & Terlalu sukar \\
\hline $0.00<\mathrm{P} \leq 0,30$ & Sukar \\
\hline $0,31<\mathrm{P} \leq 0,70$ & Sedang \\
\hline $0,71<\mathrm{P}<1,00$ & Mudah \\
\hline $\mathrm{P}=100$ & Terlalu mudah \\
\hline
\end{tabular}

\section{Daya Pembeda}

Uji daya beda dalam penelitian ini bertujuan mengetahui kemampuan suatu soal untuk membedakan antara siswa yang berkemampuan tinggi dengan siswa yang berkemampuan rendah. Rumus yang digunkan adalah sebagai berikut:

Keterangan :

$$
\mathrm{D}=\frac{B A}{J A}-\frac{B B}{J B}
$$

D : Daya pembeda

JA : Skor maksimal yang mungkin diperoleh peserta kelas atas

JB : Skor maksimal yang mungkin diperoleh peserta kelas bawah
BA : Total skor peserta kelas atas

BB : Total skor peserta kelas bawah

Klasifikasi Daya Pembeda yaitu:

\begin{tabular}{|c|c|}
\hline Tingkat Keberhasilan & Kategori \\
\hline $0.40-100$ & Sangat baik \\
\hline $0,30-0,39$ & Baik \\
\hline $0,20-0,29$ & Cukup \\
\hline $0,00-0,19$ & Jelek \\
\hline
\end{tabular}

\section{Analisis Data}

Setelah data diperoleh, kemudian dilakukan perhitungan statistik dan membandingkan hasil belajar Pretest dan Posttest. Perhitungan statistik meliputi uji persyaratan analisis dan uji hipotesis. Uji persyaratan analisis terdiri dari uji normalitas dan uji homogenitas.

\section{Uji Normalitas}

Uji normalitas digunakan untuk menentukan apakah sebaran data bersifat normal atau tidak. Uji normalitas dapat dilakukan dengan kolomogorov dan Shapiro Wilk. Untuk pengujian normalitas dalam penelitian ini menggunakan Sofware SPSS versi 21 for window dengan ketentuan hasil uji normalitas sebagai berikut:

Jika nilai sig. < 0,05 maka data berdistribusi tidak normal.

Jika nilai sig. > 0.05 maka data berdistribusi normal.

Sedangkan jika pada uji normalitas diperoleh tidak berasal dari populasi yang berdistribusi normal, maka untuk menguji hipotesis digunakan uji non parametrik. Adapun jenis uji non parametrik yang digunakan pada penelitian ini yaitu dengan Uji Wilcoxon. Adapun rumus untuk Uji Wilcoxon sebagai berikut:

Dimana:

$$
\mathrm{Z}=\frac{T-\left[\frac{1}{4 N(N+1)}\right.}{\sqrt{\frac{1}{24 N(N+1)(2 N+1)}}}
$$

$\mathrm{N}$ : Banyaknya data yang berubah setelah diberi perlakuan berbeda.

$\mathrm{T}$ : Jumlah ranking dari nilai selisih yang negative (apabila banyaknya selisih yang positif lebih banyak dari banyaknya selisih negatif).

$\mathrm{Z}$ : Jumlah ranking dari nilai selisih 
positif (apabila banyaknya selisih yang negative > banyaknya selisih positif)

Uji Hipotesis: a. Hasil Observasi Guru

Penelitian ini bertujuan untuk mengetahui proses pembelajaran dengan model cooperative learning tipe student 0 (tidak ada perbedaan diantarafacilitator and explaining. Adapun dua perlakuan yang diberikan). kelompok yang dijadikan sebagai sampel

H1 : $\quad d \neq 0$ (ada perbedaan diantara dua penelitian adalah siswa-siswi SDN perlakuan yang diberikan).

2. Uji Perbedaan Dua Rata-rata

Uji perbedaan dua rata-rata digunakan untuk mengetahui pengaruh hasil pre-test sebelum diberikan perlakuan (treatment) dan hasil post-test sesudah diberi perlakuan (treatment). Untuk mengetahui perbedaan dua rata-rata ini menggunakan uji satu pihak (uji t) yaitu uji pihak kiri. Hipotesis yang digunakan adalah sebagai berikut:

$$
\begin{aligned}
& \mathrm{H} 0: \mu_{1} \geq \mu_{2} \\
& \mathrm{H} 1: \mu_{1}<\mu_{2}
\end{aligned}
$$

Keterangan:

$\mu_{1}=$ rata-rata nilai post-test

$\mu_{2}=$ rata-rata nilai pre-test

Untuk menguji hipotesis di atas digunakan uji $t$ sebagai berikut:

Dimana

$$
t=\frac{\bar{x}_{1-\bar{x}_{2}}}{\sqrt[s]{\frac{1}{n_{1}}+\frac{1}{n_{2}}}}
$$

$$
s=\sqrt{\frac{\left(n_{1}-1\right) \mathrm{s}^{2}{ }_{1}+\left(n_{1}-1\right) \mathrm{s}^{2}{ }_{2}}{n_{1}+n_{1}-2}}
$$

Keterangan:

$\bar{x}_{1} \quad$ : rata-rata posttest

$\bar{x}_{2}$ : rata-rata pretest

$n_{1} \quad$ : Jumlah subyek posttest

$n_{1} \quad$ : Jumlah subyek pretest

$\mathrm{s}^{2}{ }_{1}$ : Standar deviasi posttest

$\mathrm{S}^{2}{ }_{2}$ : Standar deviasi pretest

Dengan kriteria pengujiannya adalah

$\mathrm{H}_{0} \quad$ jika $-t_{\text {tabel }} \leq t_{\text {hitung dimana }}$

$t_{\text {tabel }}$ didapat dari daftar distribusi $t$ dengan $d k=\left(n_{1}+n_{1}-2\right)$ dan tolak $\mathrm{H}_{0}$ untuk harga $t$ yang lain.

\section{Hasil dan Pembahasan}

1. Proses pembelajaran dengan menggunakan model cooperative learning tipe student facilitator and explaining di kelas V SDN Cikasarung
Cikasarung Kecamatan Majalengka Kabupaten Majalengka yang berjumlah 20 orang siswa. Berdasarkan hasil observasi dapat diketahui bahwa hasil observasi guru yaitu $87,50 \%$. Hal ini menunjukan bahwa ada peningkatan selama proses pembalajaran yang dilakukan guru dengan menggunakan model cooperative learning tipe student facilitator and explaining.

b. Hasil Observasi Siswa

Penelitian ini bertujuan untuk mengetahui proses pembelajaran dengan model cooperative learning tipe student facilitator and explaining. Berdasarkan hasil observasi yang dilakukan bahwa hasil observasi siswa yaitu $81,25 \%$. Hal ini menunjukan bahwa siswa sangat antusias dan aktif selama proses pembalajaran dengan penggunaan model cooperative learning tipe student facilitator and explaining. Pernyataan tersebut bersesuain dengan kelebihan model cooperative learning tipe student facilitator and explaining yaitu melatih siswa aktif dan kreatif.

2. Pengaruh model pembelajaran cooperative learning tipe student facilitator and explaining terhadap hasil belajar siswa

Bedasarkan hasil tes siswa yang didapat menunjukan bahwa siswa sangat merespon positif terhadap penerapan model pembelajaran ini, hal ini berpengaruh terhadap hasil belajar siswa yang mengalami peningkatan setelah diterapakannya model pembelajaran tersebut, itu terlihat dari data hasil pretest yang diperoleh dengan rata-rata 58,9 yang lebih besar dari nilai hasil postest dengan rata-rata 76,75 sebelum diberikan postest 
pembelajaran menggunakan model cooperative learning tipe student facilitator and explaining untuk mengetahui apakah ada peningkatan hasil belajar atau tidak, setelah treatment diberikan barulah siswa diberikan postest untuk mengetahui sejauh mana pengaruh model pembelajaran tersebut terhadap hasil belajar siswa. Terlihat dari perbandingan antara hasil pretest dan postest yang yang didapat yaitu 58,9 lebih kecil dari hasil postest yaitu 76,75. Hal ini menunjukan bahwa ada pengaruh dengan penerapan model cooperative learning tipe student facilitator and explaining terhadap hasil belajar siswa. Hal ini bersesuaian dengan kelebihan dari model pembelajaran ini yaitu mendorong tumbuhnya rasa mau mendengarkan dan menghargai pendapat orang lain, keberanian mengutarakan pendapat, mandiri, bertanggung jawab.

3. Perbedaan yang signifikan sebelum dan sesudah menerapkan model cooperative learning tipe student facilitator and explaining

Dilihat dari data pretest dan postest diperoleh hasil bahwa tidak ada perbedaan yang signifikan. Untuk mengetahui hal ini peneliti melakukan uji normalitas pada data pretest dan postest, maka dapat dilihat nilai signifikasi ini dapat disimpulkan data tersebut berdistribusi normal, karena data tersebut berdistribusi normal selanjutnya dilakukan dengan uji t, hasil output nilai signifikasi lebih besar dari 0,05 , yang berarti tidak terdapat perbedaan yang signifikan antara pretest dan postest.

Sementara itu, setelah diketahui hasil pretest dan postest dari 15 pertanyaan soal piliihan ganda dan essay yang diberikan guru kepada siswa setelah pembelajaran berakhir. Berdasarkan hasil output uji normalitas dengan menggunakan uji Shaviro-Wilk menggunakan SPSS 21 for windows dengan taraf signifikansi 0,05 , hal ini menunjukan sampel data pretest dan postest berasal dari populasi yang berdistribusi normal.
Karena data tersebut berditribusi normal maka dapat dilanjutkan dengan uji $\mathrm{t}$ menggunakan SPSS Versi 21 for Windows yaitu one sample test dan diperoleh nilai signifikasi 0,000 karena data tersebut lebih kecil dari 0,05 , hal ini menunjukan bahwa terdapat perbedaan yang signifikan hasil belajar siswa dengan menggunkan model cooperative learning tipe student facilitator and explaining.

\section{Simpulan dan Saran}

Penelitian ini bertujuan untuk mengetahui proses pembelajaran dengan model cooperative learning tipe student facilitator and explaining. berdasarkan nilai hasil observasi guru data hasil observasi guru yaitu $87,50 \%$ dan data hasil observasi siswa yaitu $81,25 \%$. Hal ini menunjukan bahwa siswa sangat antusias selama proses pembelajaran tersebut. Berdasarkan perhitungan yang telah diperoleh dalam penelitian menunjukan bahwa rata-rata pretest hasil belajar siswa sebelum perlakuan $\bar{x}=58,9$ dan rata-rata postest hasil belajar siswa sesudah perlakuan diperoleh $\bar{x}=76,75$. Berdasarkan hasil output uji normalitas dengan menggunakan uji Shaviro-Wilk menggunakan SPSS 21 for windows dengan taraf signifikansi 0,05 data pretest dan postest berasal dari populasi yang berdistribusi normal. Uji t diperoleh nilai signifikasi 0,000 karena data tersebut lebih kecil dari 0,05 maka ada pengaruh yang signifikan.

Untuk para pengguna hasil penelitian, yaitu guru bisa mendapatkan pengetahuan bahwa model cooperative learning tipe student facilitator and explaining adalah salah satu model untuk meningkatkan motivasi siswa agar berani menyampaikan pendapat dalam hasil akhir diskusi sehingga nantinya dapat menjadi alternatif yang dapat diterapkan di dalam kelas; selama proses pembelajaran, hendaknya guru memerhatikan pengelolaan kelas sehingga siswa aktif ikut serta dalam kegiatan belajar; kemudian guru dapat termotivasi untuk lebih aktif sehingga 
terjalin komunikasi yang baik antara siswa dengan siswa ataupun antara guru dengan siswa.

\section{DAFTAR PUSTAKA}

Abdulhak (2001)

Komunikasi

Pembelajaran:

Pendekatan

Konvergensi dalam Peningkatan

Kualitas dan Efeksifitas Pembelajaran.

Bandung: UPI.

Anderson dan Krathwohl. (2002). Revisi

Taksonomi Bloom. Jakarta: Rineka Cipta.

Anni, Catharina Tri, dkk. (2006). Psikologi Belajar. Semarang: UPT MKK UNNES.

Arikunto, Suharsimi. (2008). Dasar-dasar Evaluasi Guru. Jakarta: Bumi Aksara.

Asma, Nur. (2006). Model Pembelajaran Kooperatif. Jakarta: Departemen Pendidikan Nasional Direktorat Jendral Pendidikan Tinggi.

Baharuddin dan Wahyuni. (2007). Teori Belajar dan Pembelajaran. Yogjakarta: Ar-Ruzz Media Group.

Dimyati \& Mudjiono. (2009). Belajar dan Pembelajaran. Jakarta: Rineka Cipta.

Djemari, Mardapi. (2004). Pengembangan Sistem Penilaian Berbasis Kompetensi, Seminar Nasional Rekayasa Sistem Penilaian Dalam Rangka Meningkatkan Kualitas Pendidikan. Yogyakarta: HAPY.

Hidayati, dkk. (2008). Pengembangan Pendidikan IPS SD. Jakarta: Direktorat Jendral Pendidikan Tinggi Departemen Pendidikan Nasional.

Isjoni. (2009). Cooperative Learning. Bandung: Alfabeta.
Jihad, A. (2012). Evaluasi pembelajaran. Yogyakarta: Multi Pressindo.

Kusuma, Doni. (2007). Pendidikan Karakter; Strategi Mendidik Anak di Zaman Global Jakarta: Grasindo.

Mahmud. (2010). Psikologi Pendidikan. Bandung: Pustaka Setia.

Majid, Abdul. (2013). Strategi Pembelajaran. Bandung: Remaja Rosdakarya.

Purwanto. (2011). Evaluasi Hasil Belajar. Yogyakarta: Pustaka Pelajar.

Slameto. (2010). Belajar dan FaktorFaktor yang Memengaruhinya. Jakarta: Rineka Cipta.

Sugiono. (2012). Metode penelitian Kuantitatif, kualitatif, dan $R \& D$. Bandung: Alfabeta.

Suprijono. (2011). Cooperative Learning (Teori \& Aplikasi PAIKEM). Yogyakarta: Pustaka Pelajar. (2010). Cooperative Learning. Yogyakarta: Pustaka Pelajar.

Suyatno. (2009). Menjelajah Pembelajaran Inovatif. Sidoarjo: Masmedia Buana Pusaka.

Trianto (2007). Model-model Pembelajaran Inovatif Berorientasi Konstuktivistik. Jakarta: Prestasi Pustaka.

(2014). Mendesain Model Pembelajaran Inovatif, Progresif, dan Kontekstual. Jakarta: Prenada Media Group. 